
053620190116

\title{
Physiological differences of 'Crocantela' lettuce cultivated in conventional and hydroponic systems
}

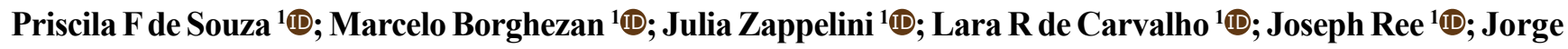 L Barcelos-Oliveira ${ }^{1} \mathbb{D}$; Rosete Pescador ${ }^{1} \mathbb{D}$}

${ }^{1}$ Universidade Federal de Santa Catarina (UFSC), Florianópolis-SC, Brazil; souza.fernandes.p@gmail.com; mborghezan@hotmail.com; juzapp@gmail.com; lara.florestal@gmail.com; joeree21@yahoo.com; j.barcelos@ufsc.br; rosete.pescador@ufsc.br

\begin{abstract}
Conventional soil and hydroponic growing systems have inherent differences in water and nutritional availability. These differences may affect plant physiological development and biochemistry. The objective of this study was to evaluate lettuce (Lactica sativa) cv. 'Crocantela'development in either a hydroponic system or in soil through analyses of vegetative growth; chlorophyll abundance; and sugar and starch content. We evaluated the dry mass (DM), fresh mass (FM), number of leaves (LN), stomatal density and contents of chlorophyll, carotenoids, sugars and starch. Due to the improved nutritional conditions, especially in relation to macronutrients, plants grown in hydroponic system presented significant differences in chlorophyll $a(0.4481 \mathrm{mg} / \mathrm{g}), b(0.1233 \mathrm{mg} / \mathrm{g})$ and total chlorophyll content $(0.5714 \mathrm{mg} / \mathrm{g})$, as well as greater biomass when compared to plants cultivated in pots (FM: $342.69 \mathrm{~g}$; DM: $21.13 \mathrm{~g}$; NL: $17.75 \mathrm{~g}$ ). The lower water availability for plants cultivated in pots influenced the increase in carbohydrate concentration and stomatal density in leaves (adaxial: 45.83 stomates $/ \mathrm{mm}^{2}$; abaxial: 64.75 stomates $/ \mathrm{mm}^{2}$ ) of lettuce plants.
\end{abstract}

Keywords: Lactuca sativa, biomass, chlorophyll, starch, stomatal density.

\section{RESUMO}

Diferenças fisiológica em alface "Croncantela" em sistema de produção convencional e hidropônico

As plantas cultivadas em sistemas a campo e em hidroponia apresentam grandes diferenças em relação a disponibilidade hídrica e nutricional, afetando o ciclo de desenvolvimento e metabólico, a anatomia dos órgãos e o desempenho das plantas devido a mudanças no comportamento fisiológico e bioquímico. O objetivo deste trabalho foi avaliar o desenvolvimento de plantas de alface da cultivar Crocantela (Lactuca sativa) cultivadas em sistema hidropônico e em vasos, através de análises de parâmetros de crescimento e fisiológicos relacionados aos processos fotossintéticos. Foram avaliados a produção de massa seca (MS), massa fresca (MF), número de folhas (NF), densidade de estômatos, teores de clorofila, carotenoides, açúcares e amido. Por proporcionar melhores condições nutricionais, principalmente em relação aos macronutrientes, plantas cultivadas em sistema hidropônico apresentaram diferenças significativas na concentração de clorofila $a(0,4481 \mathrm{mg} / \mathrm{g}), b(0,1233 \mathrm{mg} / \mathrm{g})$ e total $(0,5714 \mathrm{mg} / \mathrm{g})$, além de maior biomassa comparadas às plantas cultivadas em vaso (MF: 342,69 g; MS: 21,13 g; NF: 17,75 g). A menor disponibilidade hídrica para plantas cultivadas em vaso influenciou o aumento da concentração de carboidratos e a densidade estomática nas folhas (adaxial: 45,83 estômatos $/ \mathrm{mm}^{2}$; abaxial: 64,75 estômatos $/ \mathrm{mm}^{2}$ ) das plantas de alface.

Palavras chave: Lactuca sativa, biomassa, clorofila, amido, densidade de estômatos.

\section{Received on November 13, 2017; accepted on November 1, 2018}

$\mathrm{L}$ ettuce (Lactuca sativa) is the most cultivated and consumed vegetable in Brazil, with an estimated total production of 1,1276 million tons (Reetz et al., 2014), due to the plant's ability to adapt to diverse biomes within the country (Sala \& Costa, 2012). The Crocantela cultivar, developed by the Universidade Federal de São Carlos, is particularly well-developed for year-round cultivation in a tropical environment (UFSCar, 2013).

Currently, there are at least four widely-used systems for lettuce cultivation: conventional and organic farming in open field; hydroponic cultivation in a controlled environment; and soil cultivation in greenhouses. These four systems differ in both environment and post-production handling of the harvested lettuce (Henz \& Suinaga, 2009).

Conventional field cultivation near urban centers remains the most widelyused of these four systems (Henz \& Suinaga, 2009). However, the broad, open area in this system, with its inherent variations of temperature and precipitation, lead to subsequent variations of the product's quality, as well as to added risk of pests and pathogens incidence (Grillas et al., 2001). Long drought periods, such as the one that took place in Brazil during the summer 2014, may result in losses of both quantity and quality; excess heat can burn leaves and roots, and water deficit can lead to poor plant health and thus increase the susceptibility to disease (Reetz et al., 2014).

Hydroponics is an alternative to conventional soil-based cultivation: 
both growing environment and inputs of water and nutrients may be controlled; less work is required; growing cycles are shorter; and there is less wasted water (Paulus et al., 2012).

Plants grown in either system may reflect these differences in their resultant physiology, development cycle, anatomical structure, metabolism and biochemistry. For example, plants grown in hydroponic systems showed increased growth, in terms of greater number of leaves, dry and fresh mass, greater concentration of foliar pigments, and fewer stomata compared to plants grown in soil, although nutritional and water conditions in hydroponic systems may influence growth response (Batista et al., 2010; Rosa et al., 2014). However, studies of physiological alterations on lettuce plants grown in different production systems are still recent and scarce in the literature (Rosa et al., 2014).

The objective of this work was to evaluate the physiological, biochemical, and photosynthetic differences between lettuce cv. Crocantela plants cultivated in either soil or hydroponic growing systems.

\section{MATERIAL AND METHODS}

Lettuce cv. Crocantela plants were cultivated in two systems: hydroponics and pots filled with soil at the Hydroponics Laboratory of Universidade Federal de Santa Catarina, Florianopolis, Santa Catarina, Brazil. The study took place from March to May 2015, with temperatures ranging from $18.8^{\circ} \mathrm{C}$ to $26.4^{\circ} \mathrm{C}$ (minimum and maximum values).

Seeds were germinated in phenolic foam (two seeds per cell) in a hydroponic system until seedlings emerged. On the $10^{\text {th }}$ day, seedlings were transferred to individual cells and maintained for another 14 days. Afterwards, the $5 \pm 1$ $\mathrm{cm}$ height seedlings were cultivated either under hydroponic conditions or transferred to soil in pots in a greenhouse. Plants were placed in several lines, 0.25 $\mathrm{m}$ apart, between plants and lines; distances were equal under either soil or hydroponic systems, with density of
16 plants per $\mathrm{m}^{2}$.

Hydroponic nutrient solution was formulated according to BarcelosOliveira (2008). The electrical conductivity of the culture solution was maintained between 1.85 and $2.00 \mathrm{dSm}^{-1}$ (deciSiemens $\mathrm{m}^{-1}$ ), and corrected every two days. For soil cultivation, $2 \mathrm{dm}^{3}$ vessels were filled with substrate in the proportion 1:1:1 (peat : sand : organic compounds originated from vegetal residues) (Table 1). The field capacity of the vessels was estimated by the gravimetric method after full saturation (Schmugge et al., 1980), whose value was maintained at approximately $70 \%$ in the first irrigation. Afterwards, the vessels were watered manually two times a day in order to keep the substrate moisture.

Lettuce plants were harvested 59 days after sowing, equivalent to 37 days after transplanting, in either system. At this time, growth, stomatal density and chemical composition were evaluated in two plants per replicate, totaling 12 plants per treatment.

Growth parameters included length of the longest root length (RL); aerial height $(\mathrm{AH})$, total plant height $(\mathrm{TPH}$, equal to RL + PH); leaf number (LN); fresh root mass (FRM); fresh aerial mass (FAM); total fresh matter (TFM, equal to FRM + FAM); root dry matter (RDM); dry aerial matter (DAM); and total dry matter (TDM, equal to RDM + DAM). Samples were kept in a ventilated oven at $60^{\circ} \mathrm{C}$ for 72 hours, until a constant mass to determine dry matter.

Chlorophyll $a, b$, total chlorophyll and carotenoid contents were determined according to Hiscox \& Israeltam (1979). Fresh leaves from the middle height of the plants were collected immediately after harvest, and the foliar pigment contents were estimated according to Wellburn (1994) from several locations on the lead, excluding the regions of the larger veins.

Total soluble sugar contents were determined separately on leaves, roots and the whole plant (where: sugar content on leaves + sugar content on roots), by the phenol-sulfuric spectrophotometric method according to Dubois et al. (1956). Total carbohydrate content was estimated from the standard curve $(\mathrm{y}=$
$0.0174 \mathrm{x}+0.0156 ; \mathrm{r} 2=0.9983)$, using glucose as the standard carbohydrate. Total starch content on leaves and roots was determined according to Rosa et al. (2014).

Stomatal density was determined on two leaves per replicate using the synthetic enamel fixation method: enamel was applied on both leaf surfaces (abaxial and adaxial), and enamel was gently removed; then, the enamel sheets were places on microscopy slides. These enamel sheets were observed using an optical microscope (CH30 Olympus and BX 40 Olympus) at 200x magnification with a total visible area of $0.16 \mathrm{~mm}^{2}$. Stomata were counted in five visible frames per slide, totaling 20 readings per treatment.

Acomplete randomized experimental design was used with two cultivation systems, evaluated in experimental units containing six replicates, with six plants per experimental unit. Data of the highest root length, shoot height, whole plant height, leaf number, fresh shoot mass and total fresh mass were transformed by $\log _{10}$ for variance homogenization. Then, all data were submitted to the Cochran test to verify homoscedasticity and analysis of variance (ANOVA).

\section{RESULTS AND DISCUSSION}

Cultivation system had a significant effect on many growth parameters (Table 2). Specifically, plants grown in hydroponics showed several parameters significantly higher than plants grown in soil: LR (69.8\%); AH (115\%); TPH (85.2\%); LN (104.7\%); FRM (319.9\%); FAM (767.6\%); TFM (678.5\%); DAM (75.2\%); TDM (71.37\%), and TFM/TDM (365\%), with values in percentages reflecting how much greater mean values were in hydroponic-grown plants than in pot-grown ones (Table 2).

Evaluating two lettuce cultivars, Rosa et al. (2014) observed the greatest accumulation of biomass in plants grown in hydroponic system in relation to the soil-based conventional system. The greater accumulation of biomass observed in plants cultivated on hydroponic system is directly associated to the availability 
Table 1. Chemical composition of the substrate (peat : sand : organic compounds originated from vegetal residues) used on soil cultivation of lettuce. Florianópolis, UFSC, 2015.

\begin{tabular}{|c|c|c|c|c|c|c|c|c|}
\hline \multirow{2}{*}{ Clay $(\% \mathrm{~m} / \mathrm{v})$} & \multirow{2}{*}{$\begin{array}{c}\text { Organic matter } \\
(\% \mathrm{~m} / \mathrm{v})\end{array}$} & \multirow{2}{*}{ Water (pH 1:1) } & \multirow{2}{*}{ SMP index } & $\mathbf{P}$ & $\mathbf{K}$ & Al & $\mathbf{C a}$ & Mg \\
\hline & & & & \multicolumn{2}{|c|}{$\left(\mathrm{mg} / \mathbf{d m}^{3}\right)$} & & \multicolumn{2}{|c|}{$\left(\mathrm{dmolc} / \mathrm{dm}^{3}\right)$} \\
\hline 13 & 3.9 & 5.6 & 6.2 & 157.5 & 474.7 & 0.0 & 11,2 & 6,3 \\
\hline \multirow{2}{*}{$\mathbf{H}+\mathbf{A l}\left(\mathbf{c m o l c} / \mathbf{d m}^{3}\right)$} & \multirow{2}{*}{ CTC (pH 7.0) } & \multirow{2}{*}{$\mathrm{Al}\left(\mathrm{cmolc} / \mathbf{d m}^{3}\right)$} & Bases & $\mathbf{K}$ & Ca & & Mg & \\
\hline & & & \multicolumn{6}{|c|}{ (\% saturation in CTC) } \\
\hline$\overline{3.47}$ & 22.18 & 0.0 & 84.37 & 5.47 & 50.50 & & 28.40 & \\
\hline
\end{tabular}

$\mathrm{m} / \mathrm{v}$ : mass/volume; SMP index: Shoemaker, Mac Lean and Pratt index.

of nutrients in the nutrient solution, as well as the lower water stress. The lower carbon consumption for the production of lignin and cellulose, involved in cell wall stiffness, results in the production of less-fibrous plants and more-succulent leaves (Cometti et $a l ., 2004)$. However, it is possible that plants grown in pots may have limited root growth, and consequently, less biomass accumulation.

Curiously, RDM was not significantly different between the two systems, despite the large differences in other parameters. These results suggest that, although the potted plants showed a lower growth of the aerial part, they put greater importance on developing their root system compared to those grown under hydroponic conditions. Hydroponic plants grew longer roots on average compared to those grown in soil, but they grew fewer in total, leading to non-significant differences between either treatment. These results differ from those observed by Cometti et al. (2004), who reported higher carbon investment in the root system of potted plants.

Hydroponic cultures had higher values for TFM and TDM (Table $2)$. These results differ from those observed by Rosa et al. (2014) who reported lower dry matter content, due to greater hydration of the leaves of the plants grown in hydroponics. However, Fernandes et al. (2004) obtained higher total fresh mass in the production of basil (Ocimum basilicum) in hydroponic system when compared to the cultures in commercial and prepared substrates, with a production of about $44 \%$ more TFM.

Cultivation system, similarly to growth characteristics, significantly affected the photosynthetic capacity of lettuce plants (Table 3). Hydroponicgrown plants contained $135.7 \%$, $69.6 \%$, and $117.4 \%$ higher chlorophyll $a, b$, and total, respectively. These results suggest a higher photosynthetic efficiency of plants grown in hydroponic medium, which was likely reflected in the higher production of biomass.

Table 2. Mean values for root length (RL), aerial height (AH), total plant height (TPH), leaf number (LN), fresh root mass (FRM), fresh aerial mass (FAM), total fresh mass (TFM), dry root mass (DRM), dry aerial mass (DAM), total dry mass (TDM) and ratio of total fresh mass over total dry mass (TFM/TDM) of lettuce (Lactuca sativa cv. Crocantela) cultivated in soil (pots) and in a hydroponic system. Florianópolis, UFSC, 2015.

\begin{tabular}{|c|c|c|c|c|c|c|}
\hline \multirow{2}{*}{ System } & RL & $\mathbf{A H}$ & TPH & \multirow{2}{*}{$\mathbf{L N}$} & FRM & FAM \\
\hline & \multicolumn{3}{|c|}{ (cm) } & & \multicolumn{2}{|c|}{ (g) } \\
\hline Soil & $30.00 \mathrm{~b}$ & $15.46 \mathrm{~b}$ & $45.46 \mathrm{~b}$ & $8.67 \mathrm{~b}$ & $8.77 \mathrm{~b}$ & $35.25 \mathrm{~b}$ \\
\hline \multirow[t]{3}{*}{ Hydroponics } & $50.95 \mathrm{a}$ & $33.25 \mathrm{a}$ & $84.21 \mathrm{a}$ & $17.75 \mathrm{a}$ & $36.83 \mathrm{a}$ & $305.85 \mathrm{a}$ \\
\hline & TFM & DRM & DAM & TDM & \multirow{2}{*}{\multicolumn{2}{|c|}{$\begin{array}{l}\text { TFM/ } \\
\text { TDM }\end{array}$}} \\
\hline & \multicolumn{4}{|c|}{ (g) } & & \\
\hline Soil & $44.02 \mathrm{~b}$ & $0.879 \mathrm{a}$ & $11.45 \mathrm{~b}$ & $12.33 \mathrm{~b}$ & $3.55 \mathrm{~b}$ & \\
\hline Hydroponics & $342.69 \mathrm{a}$ & $1.070 \mathrm{a}$ & $20.06 \mathrm{a}$ & $21.13 \mathrm{a}$ & $16.51 \mathrm{a}$ & \\
\hline
\end{tabular}

Means followed by same letters in same columns do not differ statistically from each other (F test).

Rosa et al. (2014) also found a higher concentration of chlorophylls $a, b$ and total in the cultivated lettuce in hydroponics, although with less pronounced differences.

The constant flow of nutrient media to plants in hydroponic systems likely resulted in conditions more favorable than soil cultivation, resulting in plants with significant difference in chlorophyll. Also, the greater water availability in hydroponic cultivation may explain the higher contents of chlorophyll a and $b$, since the lower water availability was associated with the reduction in chlorophyll content, such as in observations made for Gossypium hirsutum (Parida et al., 2007), Catharanthus roseus (Jaleel et al., 2008) and lettuce (Rosa et al., 2014). Chlorophyll $a$ was more prevalent than chlorophyll $b$ in either system. These results are similar to the results of Rosa et al. (2014), who found that chlorophyll $a$ made up about $75 \%$ of total chlorophyll.

Except the starch content in the roots, statistical differences were observed in the contents of soluble sugars in the leaves, roots and total, and in the content of starch in the leaves (Table 4). The soluble sugars levels in leaves, roots and total were higher $(23.8 \%, 108 \%$, $61.5 \%$, respectively) in potted plants when compared to hydroponic cultivars. However, leaf starch content was $14.28 \%$ higher in hydroponic culture when compared to those in soil.

Since water availability is not constant throughout the day in potted plants, unlike under hydroponic cultivation, the higher sugar and starch content in plants grown in soil may be explained by osmotic adjustment, that is, the accumulation of intracellular 
Table 3. Mean values of chlorophyll $a$, chlorophyll $b$, total chlorophyll (mg/g), chlorophyll $a / b$ ratio and total carotenoids (mg/g) of lettuce (Lactuca sativa cv. Crocantela) cultivated in pots and in hydroponics. Florianópolis, UFSC, 2015.

\begin{tabular}{lccccc}
\hline System & Chlorophyll $\boldsymbol{a}$ & Chlorophyll $\boldsymbol{b}$ & Chlorophyll total & Chlorophyll $\boldsymbol{a} / \boldsymbol{b}$ & Total carotenoids \\
\hline Soil & $0.1901 \mathrm{~b}$ & $0.0727 \mathrm{~b}$ & $0.2628 \mathrm{~b}$ & $2.8091 \mathrm{a}$ & $0.0856 \mathrm{a}$ \\
Hydroponics & $0.4481 \mathrm{a}$ & $0.1233 \mathrm{a}$ & $0.5714 \mathrm{a}$ & $3.7611 \mathrm{a}$ & $0.1053 \mathrm{a}$ \\
\hline
\end{tabular}

Means followed by same letters in same columns do not differ statistically from each other (F test).

Table 4. Mean values of leaf, root, and total sugars; and mean values of leaf and root starch in lettuce (Lactuca sativa cv. Crocantela) cultivated in soil pots and in hydroponics system ( $\mu \mathrm{g}$ equivalent to glucose/g of fresh mass). Florianópolis, UFSC, 2015.

\begin{tabular}{lccccc}
\hline System & Leaf sugar content & Root sugar content & Total sugar & Leaf starch content & Root starch content \\
\hline Soil & $0.01436 \mathrm{a}$ & $0.0192 \mathrm{a}$ & $0.0336 \mathrm{a}$ & $0.0098 \mathrm{~b}$ & $0.0103 \mathrm{a}$ \\
Hydroponics & $0.0116 \mathrm{~b}$ & $0.0092 \mathrm{~b}$ & $0.0208 \mathrm{~b}$ & $0.0112 \mathrm{a}$ & $0.0136 \mathrm{a}$ \\
\hline
\end{tabular}

Means followed by same letters in same columns do not differ statistically from each other by the $\mathrm{F}$ test.

solutes. This is an important mechanism for the maintenance of cellular turgidity, which mainly allows the maintenance of stomatal opening and photosynthetic processes under conditions of low soil water availability (Vieira Junior et al., 2007). The increase in total soluble sugars as a response to water stress was also observed in Solanum lycocarpum (Chaves Filho \& Stacciarini-Seraphin, 2001), Schizolobium amazonicum and Schizolobium parahyba (Carvalho, 2005). According to Szegletes et al. (2000), the accumulation of soluble sugars and starch, besides providing advantages from the point of view of lower osmotic potential and the maintenance of turgidity, serves as carbon and nitrogen reserves for the immediate resumption of growth once environmental conditions become more favorable. The low soluble sugars in the roots of hydroponic lettuce can be the result of the partially ammoniacal nutrition $(12.5 \%)$ of the composition of nutritive solution (Furlani, 1997), since the absorbed ammonium could be immediately incorporated in the roots, increasing the demand for photoassimilates (Cometti et al., 2004).

Both adaxial and abaxial sides of lettuce leaves had stomata, therefore characterizing lettuce as amphistomatic. However, potted plants presented higher stomata density on either sides (45.83 and 64.75 stomata $/ \mathrm{mm}^{2}$, respectively adaxial and abaxial) in relation to the hydroponic system (32.81 and 36.97 stomata $/ \mathrm{mm}^{2}$, respectively adaxial and abaxial).
Quantity, distribution, size, shape and mobility of stomata are speciesspecific characteristics and can be altered as a function of adaptation to environmental conditions (Larcher, 2000). In environments with less water availability, there is a decrease in the size of the stomata, so that there is a lower water loss of the plant by transpiration, with the simultaneous increase of its density, contributing to the balance of gas exchange (Batista et al., 2010). This description is compatible with the observed results, indicating that the lower availability of water in the soil system resulted in a higher density of stomata.

The cultivation system affects development, metabolism and leaf structure of lettuce plants. Plants grown in the hydroponic system presented higher water content, resulting in a larger size and accumulation of biomass. Water availability influences the carbohydrate concentration and the stomatal density of lettuce plants. Plants grown in the hydroponic system present greater vegetative growth and chlorophyll, but plants grown in soil, in general, contained higher carbohydrates and a greater stomata density.

\section{REFERENCES}

BARCELOS-OLIVEIRA, JL. 2008. Formulação de correção para alface hidropônica em sistema NFT, com plantas de mesma idade na bancada final. In: II ENCONTRO SUL-BRASILEIRO DE HIDROPONIA. Anais... Florianópolis: TecArt Editora. p. 18-25.
BATISTA, LA; GUIMARÃES, RJ; PEREIRA, FJ; CARVAlHO, GR; CASTRO, EM. 2010. Anatomia foliar e potencial hídrico na tolerância de cultivares de café ao estresse hídrico. Revista Ciência Agronômica 41: 475-481.

CARVAlHO, CJR. 2005. Respostas de plantas de Schizolobium amazonicum $[S$. parahyba var. amazonicum] e Schizolobium parahyba[Schizolobium parahybum] à deficiência hídrica. Revista Arvore 29: 907914.

CHAVES FILHO, JT; STACCIARINISERAPHIN, E. 2001. Alteração no potencial osmótico e teor de carboidratos solúveis em plantas jovens de lobeira (Solanum lycocarpum St.-Hil.) em resposta ao estresse hídrico. Revista Brasileira de Botânica 24: 199-204.

COMETTI, NN; MATIAS, GCS; ZONTA, E; MARY, W; FERNANDES, MS. 2004. Compostos nitrogenados e açúcares solúveis em tecidos de alface orgânica, hidropônica e convencional. Horticultura Brasileira 22: 748-753.

DUBOIS, M; GILLES, KA; HAMILTON, JK; REBERS, PA; SMITH, F. 1956. Colorimetric method for determination of sugars and related substances. Analytical Chemistry 28: 350-356.

FERNANDES, PC; FACANALI, R; TEIXEIRA, JPF; FURLANI, PR; MARQUES, MOM. 2004. Cultivo de manjericão em hidroponia e em diferentes substratos sob ambiente protegido. Horticultura Brasileira 22: 260264.

FURLANI, PR. 1997. Instruções para o cultivo de hortaliças de folhas pela técnica de hidroponiaNFT. Campinas: Instituto Agronômico, 30p. (Boletim técnico, 168).

GRILLAS, S; LUCAS, M; BARDOPOULOU, E; SARAFOPOULOS, S. 2001. Perlite based soilless culture systems: current commercial applications and prospects. Acta Horticulturae 548: 105-113.

HISCOX, JD; ISRAELTAM, GF. 1979. A method for the extraction of chlorophyll from leaf tissue without maceration. Canadian Journal of Botany 57: 1332-1334.

HENZ, GP; SUINAGA, F. 2009. Tipos de alface 
cultivados no Brasil. Brasília: Embrapa Hortaliças, 7p. (Comunicado técnico, 75).

J A L E E L, C A; M A N I VA N N A N, P ; L A K S H A N A , GMA; G O M A T H I N A Y A G A M, M ; PANNEERSELVAM, R. 2008. Alterations in morphological parameters and photosynthetic pigment responses of Catharanthus roseus under soil water deficits. Colloids and Surfaces B: Biointerfaces 61: 298-303.

LARCHER, W. 2000. Ecofisiologia vegetal. São Carlos: Rima. 531p.

PARIDA, AK; DAGAONKAR, VS; PHALAK, MS; UMALKAR, GV; AURANGABADKAR, LP. 2007. Alterations in photosynthetic pigments, protein and osmotic components in cotton genotypes subjected to short-term drought stress followed by recovery. Plant Biotechnoogyl Reports 1:37-48.
PAULUS, D; PAULUS, E; NAVA, GA.; MOURA, CA. 2012. Crescimento, consumo hídrico e composição mineral de alface cultivada em hidroponia com águas salinas. Revista Ceres 59: 110-117.

REETZ, ER; KIST, BB; SANTOS, CE; CARVALHO, C; DRUM, M. 2014. Anuário brasileiro de hortaliças. Santa Cruz do Sul: Editora Gazeta Santa Cruz.

ROSA, MA; SEÓ, HLS; VOLPATO, MB; FOZ, NV; SILVA, TC; OLIVEIRA, JLB; PESCADOR, R; OGLIARI, JB. 2014. Production and photosynthetic activity of Mimosa verde and Mimosa roxa lettuce in two farming systems. Revista Ceres 61: 494-501.

SALA, FC; COSTA, CP. 2012. Retrospectiva e tendência da alfacicultura brasileira. Horticultura Brasileira 30: 187-194.

SZEGLETES, Z; ERDEI, L; TARI, I; CSEUZ,
L. 2000. Accumulation of osmoprotectants in wheat cultivars of different drought tolerance. Cereal Research Communications 28: 403410.

UFSCar. 2013. UFSCar desenvolve nova variedade de alface. Informativo FAIUFSCar, n. 133 , ano 14 , p. 3 ,

VIEIRA JUNIOR, PA; DOURADO NETO, D; OLIVEIRA, RF; PERES, LEP; MARTIN, TN; MANFRON, PA; BONNECARRÈRE,

RAG. 2007. Relações entre o potencial e a temperatura da folha de plantas de milho e sorgo submetidas a estresse hídrico. Acta Scientiarum Agronomy 29: 555-561.

WELLBURN, AR. 1994. The spectral determination of chlorophylls a and $\mathrm{b}$, as well as total carotenoids, using various solvents wiht spectrophotometers of different resolution. Journal of Plant Physiology 144: 307-313. 